\title{
Question Formation and Working Memory Capacity on L2 Reading Comprehension
}

Elaboração de Perguntas, Memória de Trabalho e a Compreensão Leitora em L2

\section{Luciane Baretta}

Universidade Estadual do Centro-Oeste - UNICENTRO - Guarapuava - Paraná - Brasil

\section{Maria da Glória Guará Tavares}

Universidade Federal do Ceará - UFC - Fortaleza - Ceará - Brasil

\begin{abstract}
The assessment of reading comprehension is an issue that has motivated a considerable amount of studies. Many of these have shown that the variables of readers' characteristics, types of texts, subsequent task of reading comprehension and language do influence the way one approaches a text. In this paper, the extent to which the ability to formulate questions about a text correlates with working memory capacity was examined. Eleven L2 (foreign, second, additional language) graduate students performed a reading span test and a reading task which required them to read two expository texts and formulate one question at the end of each paragraph of each of the texts. Results indicated that, although there was not a statistically significant correlation between textually implicit and scripturally implicit questions and working memory capacity, these types of questions were more frequent for those readers with a higher working memory capacity, suggesting that they are more prone to make inferences.
\end{abstract}

Keywords: Question formation. Working memory capacity. Reading comprehension. L2.

Resumo: A avaliação da compreensão leitora é um tema que tem motivado um número considerável de pesquisas. Muitos estudos mostram que as variáveis relativas às características dos leitores, tipos textuais, tarefa subsequente à compreensão e a língua do texto influenciam a maneira que os leitores abordam o material sendo lido. Neste artigo, é investigada a relação entre a habilidade do leitor de formular perguntas sobre um texto e a sua capacidade de memória de trabalho. Onze estudantes de pósgraduação em inglês como língua estrangeira/segunda língua/língua adicional realizaram um Teste de Alcance em Leitura e leram dois textos expositivos para formular uma pergunta ao final de cada parágrafo de cada um dos textos. Os resultados indicaram que, apesar de não haver uma correlação estatisticamente significativa entre as perguntas do tipo textual implícito e implícito no script, esses tipos de perguntas foram mais frequentemente formulados pelos participantes com maior capacidade de memória de trabalho, sugerindo que eles geraram maior número de inferências ao ler os textos.

Palavras-chave: Elaboração de perguntas. Capacidade de memória de trabalho. Compreensão leitora. L2. 


\section{Introduction}

The question of what goes on in the reader's mind from the focusing of the eyes in the printed page until comprehension is achieved is an issue that has been the focus of much research and debate. Many studies have shown that the variables of (a) readers' characteristics (AFFLERBACH, 1990; KAMAS; REDER, 1995; KINTSCH; FRANZKE, 1995; TOMITCH, 1996, 1999-2000, 2003; GUARÁ TAVARES, 2008), (b) types of texts (HARE, 1992; CARRELL, 1992; GOLDMAN, 1997; BARETTA; TOMITCH; MCNAIR; LIM; WALDIE, 2009; BARETTA; TOMITCH; LIM; WALDIE, 2012), (c) subsequent task of reading comprehension (RILEY; LEE, 1996; NARVAEZ; VAN DEN BROEK; RUIZ, 1999; BARETTA, 2003) and (d) language: $L 1$ or $L 2$ (WINOGRAD, 1984; WOLF, 1993; TORRES, 2003; DAROS, 2016) do influence the way one approaches a text. It is common ground, however, that when reading a text, one has to construct a mental representation of it through the integration of information across sentences (KINTSCH; VAN DIJK, 1978; VAN DIJK; KINTSCH, 1983; KINTSCH; RAWSON, 2013; SUH; TRABASSO, 1993; VAN DEN BROEK; RISDEN; FLETCHER; THURLOW, 1995; GERNSBACHER, 1997; VAN DIJK, 1999). This mental representation is thought to be a "joint product" of the text based information and the reader's preexisting shemata (WHITNEY; RITCHIE; CLARK, 1991). Much of research in this area has investigated how and to what extend inferences are generated to attain comprehension.

Although there is some disagreement in the literature about the nature and extent of the inferences that are drawn on-line (during the course of comprehension) or off-line (generated during a latter task) (GRAESSER; KREUZ, 1993; O'BRIEN, 1995) discourse-processing researchers agree that inference generation plays an important role in the construction of meaning derived from texts (VAN DIJK; KINTSCH, 1983; KINTSCH; RAWSON, 2013; NARVAEZ; VAN DEN BROEK; RUIZ, 1999).
For the past 40 years, a considerable amount of work has been done in order to investigate inference generation. Paris and his colleagues (1983) review some studies carried out with young children, good and poor readers who benefited from strategy instruction that promoted inferences during reading. According to the results of those experiments, most of the subjects improved their inferential comprehension after instruction. Zwaan and Brown (1996) observed that L1 (mother tongue) / skilled participants generated a large number of explanatory inferences, maintained the flow of their reading retrieving previous excerpts and constructed strong mental representations of the text. L2 (second, foreign or additional language) / less skilled readers, on the other hand, showed minimal integrative process and weak representations of the text. Trabasso and Magliano (1996) identified through think-aloud protocols that readers try to understand narratives by striving for coherence - which is explanatory in nature - in their interpretation of the text, using both backward and forward causal inferences to integrate textual information. Narvaez, van Den Broek and Ruiz (1999) assessed what types of inferences readers make under different reading orientations: reading for entertainment and reading for study. The participants read two narrative literary texts and two expository texts. Two texts were read using think-aloud protocol and the other two were read silently. Analyses demonstrated that reading purpose and the type of text did influence the kind and quantity of inference activities generated during reading.

As one can assume from the above-mentioned studies, there are variations in the extent to which particular types of inferences or activations are made as the reader tries to use her background knowledge as well as the elements that are in the text in order to comprehend it. Among these factors, are the language of assessment (ZWAAN; BROWN, 1996); reading ability (VAN DEN BROEK; RISDEN; HUSEBYE-HARTMANN, 1995); circumstances imposed by the task (MAGLIANO; TRABASSO; GRAESSER, 1999; NARVAEZ; VAN DEN BROEK; RUIZ, 1999); background / relevant knowledge 
(HALLDORSON; SINGER, 2002) and memory capacity (SINGER et al., 1992), which is one of the issues investigated in this paper. In order to explore the possible influence of working memory capacity on the generation of inferences, this study will consider the task of reader-generation questions to assess the cognitive content involved in the reading of expository prose by proficient L2 readers. In the next section, studies involving the use of reader-generated questions will be reviewed.

\section{Question formation}

The assessment of reading comprehension is an issue that has motivated considerable research. Basically, the so-called reading comprehension tests are divided into two modes of response: the global mode which involves integrative tasks, such as summaries and recall protocols and the discrete-point tasks which relate to specific parts of textual information, i.e., matching, true-false, multiple-choice, open-ended questions and others (RILEY; LEE, 1996).

Post-reading questions have been widely accepted as measures of reading comprehension. Nevertheless, Gerot (2000) observes that some of the comprehension questions of textbooks designed for children are flawed, as well as the texts themselves. This author noticed that since most of the texts were limited to few paragraphs, some of them were truncated as genres - there was no orientation and resolution stages for some of the narratives analyzed and some of the questions generated in the textbook contradicted the text just presented. In a similar vein, Oliveira (2000) investigated to what extent critical thinking has been fostered by question-asking in Portuguese textbooks for Brazilian high-schoolers. From the 60 questions considered in her analysis, $46,6 \%$ of them were questions related to explicit, literal information. According to Oliveira, this result reveals the traditional teacher-centered pedagogy which emphasizes the delivery of instruction, not learning, and the text is seen as a final product that has information in it and not around it (p. 48, emphasis in the original).
These two studies provide further support to DuBravac and Dale's (2002) and Miciano's (2004) arguments for a shift from textbook/teacherformulated questions to reader-generated questions . According to their review of literature, several studies have demonstrated that student-generated questions increase the comprehension and retention of narratives and that the ability to ask good questions improves one's comprehension of a text.

Carr and Ogle (1987) for instance, in their reading-thinking technique, the "K-W-L Plus" demonstrated that high school students started to transfer its use to new situations "because they have concrete evidence that they were successful in eliciting information from the text" (p.631). This technique aims at helping students to assess their reading through three steps: listing of what is Known about the topic to be read; questioning of What is wanted to know and mapping and summarizing of what was Learnt during reading. Balajthy (1983, as cited in DuBRAVAC; DALE, 2002), examined how L1 college-freshman readers with some or no training on how to form questions related to expository texts performed on comprehension tests. No difference was observed among the groups' scores for the tests performed immediately after reading, but there was a significant difference on the tests given one and five weeks after reading the most difficult texts.

Regarding the issue of inference generation, DuBravac and Dalle (2002) investigated through the question-formation methodology how undergraduate students perform while reading L2 narratives and expository texts. According to their analysis, participants generated significantly more inferential types of questions while reading narratives and more miscomprehension and literal questions while reading expository texts, corroborating previous research and suggesting that reader-created questioning is a valid measure of on-line comprehension (p. 226).

Miciano (2004) investigated the cognitive content and the linguistic form of college readersgenerated questions while reading three prose and two graph texts. Analyses demonstrated that the most common type of question generated was the recall type $(48 \%)$, followed by analysis $(13,85 \%)$ and 
comprehension types (13\%), demonstrating that students did little deep text processing, a fact that was even more highlighted by the lack of questions interrelating the three prose texts which were about the same topic - September 11th attack (p. 152). According to Miciano, the types of question generated by the students are not adequate to the higher-level processing demanded in terciary education readings: application, synthesis and evaluation of information.

Having the studies reviewed so far in mind, the present study will consider the task of readergeneration questions to assess the cognitive content involved in the reading of expository prose by proficient $L 2$ readers. As stated in the introduction, it is the objective of this research to verify to what extent inference generation in expository texts is influenced by working memory capacity, the topic of the following section.

\section{Working Memory}

Working memory can be defined as the limited capacity cognitive system responsible for temporary simultaneous storage and processing of information retrieved from long term memory during the performance of complex cognitive tasks such as reading and problem solving (BADDELEY; $\mathrm{HITCH}$, 1974; BADDELEY, 1998, 2011; DANEMAN, 1991).

The term working memory is an updated conception of the 1968 Atkinson-Shiffrin's model, that visualized memory as a unitary, short-term memory system without any subsystems. Proposed by Baddeley and Hitch in 1974, working memory depicts a multi-component storage, formed by multiple specialized components, with a system that deals with temporary storage and processing of online information (SEARLEMAN; HERRMANN, 1994; ASCHCRAFT, 1994; FORTKAMP, 2000; TOMITCH, 2003; GUARÁ TAVARES, 2008; TORRES, 2003; MATIELO, 2016). With time, Baddeley and Hitch's model underwent several theoretical refinements and in 2000, Baddeley proposes an elaboration of the original tripartite model. Baddeley's version of working memory is comprised of a central executive, responsible for orchestrating one's focus of attention, and three slave subsystems, namely: the phonological loop, the visuospatial sketchpad and the episodic buffer (BADDELEY, 2011).

In a nutshell, the central executive - the most complex component of working memory - is an attentional control system that manages one's capacity to focus their attention in the task(s) undertaken and to share the attentional resources between two or more tasks, as for instance, driving and talking to a passenger. The phonological loop the most investigated component of the system (BADDELEY, 2011) - is responsible for processing the phonological code and comprises a phonological store, which holds information that is suppressed with time, and an active rehearsal process, which recycles this information in the phonological store to keep it enhanced. Another component, the visuospatial sketchpad, is a passive visual cache, responsible for holding visual information and an active spatially based system, the inner scribe, responsible for retaining sequences of movements (BADDELEY, 1990, 1999; BADDELEY; LOGIE, 1999). The third component of the system (introduced by Baddeley in 2000), the episodic buffer, consists of a "multidimensional code that allows the interaction of various subcomponents of working memory with the long-term memory" (BADDELEY, 2011, p. 66, authors' translation ). As stated by Baddeley (2011), the understanding of this component is still in its infancy, but it comes to explain how the phonological loop and visuospatial sketchpad subsystems interact directly with the long-term memory, a fact that was not clear in the former versions of the model.

According to Baddeley (1992, 2011), research on working memory has developed from two approaches, namely, the dual-task neuropshychological approach and the psychometrical correlational approach. The dual-task approach is concerned with explaining the structure of the working memory itself, emphasizing its subsystems, namely the visuospatial sketchpad, the episodic buffer and the phonological loop. The psychometric correlational approach postulates that 
individual differences in reading comprehension may reflect differences in working memory capacity, specifically in the trade-off between its processing and storage functions, for these two functions of working memory compete for its limited capacity (DANEMAN; CARPENTER, 1980).

A test was developed by Daneman and Carpenter (1980) to tap both storage and processing functions of working memory, the Reading Span Test. This test encompasses the two components - storage and processing - by joining the demands of sentence comprehension (processing) and the storage and retrieval of final words of sentences (storage). The Reading Span Test was the first valid measure of working memory capacity (ENGLE, 1996), and, according to Fortkamp (1999), it has been the basis of most of the research on individual differences in working memory capacity and reading comprehension.

Daneman and Carpenter (1980) carried out a study in which performance on the working memory span test was correlated with a traditional assessment of comprehension (Verbal SAT scores), and it was even more correlated with performance on the two specific comprehension tests: fact questions, and pronominal reference questions; Daneman and Carpenter (1983) correlated the performance on the working memory span test with the ability to perceive lexical ambiguity in "garden path sentences"; Daneman and Green (1986) correlated performance on the working memory reading span test with the ability to use contextual cues to find the meaning of new words; Whitney, Ritchie and Clark (1991) correlated working memory capacity with the ability to use elaborative inferences in reading comprehension; Tomitch $(1996,2000,2003)$ correlated performance on the working memory span test with the ability to perceive text structure, and with the ability to recall predictive signals and predicted elements respectively; Linderholm and van den Broek (2002) correlated performance on the working memory span test with the ability to adjust cognitive processes on the processing of expository texts under different reading purposes; Torres (2003) correlated performance on the working memory reading span test and the ability of constructing main ideas in L1 and $\mathrm{L} 2$.

The studies briefly mentioned above, although from different perspectives, correlated working memory with reading ability. The present study aims at verifying the correlation on the working memory reading span test designed by Harrington and Sawyer (1992), adapted by Torres (2003), and the generation of inferences, i.e, the elaboration of questions that are implicitly stated in expository prose. The prediction of the present study is that since working memory capacity is a good predictor of reading ability, individuals with higher working memory capacity will formulate a greater number of inferential questions, namely, textually implicit and scripturally implicit questions (DUBRAVAC; DALLE, 2002). Therefore, the present study pursues four research questions:

(1) Will there be a significant correlation between textually implicit and scripturally implicit questions and working memory capacity?

(2) Will there be a significant difference between the types of questions elaborated in the two expository texts?

(3) Will participants with higher working memory capacity formulate more textually implicit and scripturally implicit questions than individuals with lower working memory capacity?

(4) Will there be a significant difference in the number (\%) of textually implicit and scripturally implicit questions formulated by better and weaker readers across the two texts?

\section{Method}

\subsection{Context and Participants}

The eleven participants (3 male, 8 female) were native speakers of Brazilian Portuguese, and speakers of English as L2. All were enrolled in a graduate course at a university in the South of Brazil, studying either applied linguistics or literature in English. Ten of the participants were master's students and one was taking her doctoral studies. The main reason for choosing this group of participants 
was their level of proficiency in English, which was expected to range from upper-intermediate to advanced. In the present study, language proficiency is defined as "a person's skill in using a language for a specific purpose" (RICHARDS; PLATT; PLATT, 1992, p.204). Since all of them had undergone a written and oral entrance examination in English, they are required to speak English in class and to write research papers in English. Moreover, all of them were English teachers at the time of data collection or have been teachers before. A certain degree of uniformity in language proficiency is desirable for this study, so that differences in the results of the experiment can be attributed to individual differences in working memory capacity and not to differences in language proficiency.

\subsection{Materials}

Materials consisted of a working memory reading span test developed by Harrigton and Sawyer (1992), adapted by Torres (2003), and a pack containing two texts of approximately 600 words each. The first text is entitled Like hitting a wall and the second Melting away. The complete texts can be found in the Master's Thesis of the first author, available

at:

http://repositorio.ufsc.br/xmlui/handle/123456789/773

66 . The first text dealt with the safety and/or danger of the use of air bags for children, and the second one dealt with tourism decline in the European Alps.

\subsubsection{The Working memory reading span test}

The working memory reading span test used in this study was the one used by Torres (2003) in her research. In most studies, working memory capacity is related to reading comprehension in L1 (TORRES, 2003). Because participants of her study were Brazilian Portuguese speakers, the working memory reading span test underwent some changes in order to avoid floor effects due to difficulties of the memory test. Thus, Torres (2003) adapted Harrington and Sawyer (1992)'s test instead of using Daneman and
Carpenter (1980)'s. The test contained 42 sentences, ranging from 11 to 13 words in length, each ending in a short noun, one syllable in length (for the visualization of the complete test, see TORRES, 2003).

\subsubsection{Texts used in the study}

The texts chosen for this study were collected from Newsweek - a weekly magazine published in the United States. Since all the participants were graduate students, they were considered proficient readers of English. The criteria for text selection were first, based on the topic, which should contain general information; the second consideration was based on the similar number of words, textual distribution (number of paragraphs), level of lexical density (51,06\% for Like hitting a wall and $55,53 \%$ for Melting away) and finally, the texts should be structured according to the rhetorical function of exposition and rhetorical pattern of problem-solution, as described in Hoey (1983). The problem-solution pattern was chosen for this study due to its wide use in both $\mathrm{L1}$ and L2 classrooms (DAVIES, 1995), a fact that suggests the participants' awareness of this kind of text structure, which according to some data, may help their performance on the tasks.

The two texts used in the present study were used in previous research by Baretta (1998, 2003), and some of the participants of this previous research considered the texts somewhat difficult, which was also part of the criteria for text selection since individual differences in working memory capacity tend to emerge when the tasks being performed offer some degree of difficulty, thus, placing much constrain on resources (JUST; CARPENTER, 1992; CARPENTER; MYIAKE; JUST, 1994).

The two texts were typed and at the end of each paragraph one asterisk and two lines were placed to signal that the participants should formulate a question related to the previous paragraph. 


\subsection{Procedures}

All participants carried out the experiments in the same fixed order: reading span test, reading comprehension task and interviews. Each participant was run individually and told the order of the experiments a priori. First, they carried out the reading span test. The 42 sentences were presented visually on a computer screen one at a time and participants had to read them aloud, then judge whether they were grammatically correct or not. Individual sentences were displayed at a rate of 9 seconds in the middle of the screen. Sentences were presented in sets of increasing length. That is, sentences were divided in 12 sets ( 3 sets of 2 sentences, 3 sets of 3 sentences, 3 sets of 4 sentences, and 3 sets of 5 sentences). Having read the last sentence in each set, participants were presented with question marks "?". They were presented with 2, 3, 4 or 5 question marks according to the number of words they were supposed to recall.

Before starting the reading span test itself, participants were provided with a training session containing one set of 2 sentences, one of 3 sentences, one of 4 sentences and one of 5 sentences. Participants were allowed to do the training session twice if they felt the need to do so. After carrying out the training session, participants were told to make themselves comfortable for starting the span test. Participants' performance on the test was recorded and transcribed for further scoring and analysis.

After finishing the reading span test, participants read the texts (Like hitting a wall first and Melting away secondly), and formulated questions at the end of each. Each text had five paragraphs, thus, participants formulated 10 questions each. Participants received written instructions on the reading tasks, which were adapted instructions from Dubravac and Dalle (2002).

When participants finished the reading comprehension tasks, they answered three interview questions asked by one of the researchers. The first question concerned the general difficulty of the text. The second question asked which text they had considered the most difficult and the third dealt with the questions they had formulated. According to Dubravac and Dalle (2002), one of the limitations of their study was that they carried out no interview to hear participants' voices about the difficulty of the texts and the way they formulated questions. Thus, following Dubravac and Dalle's suggestions, there was the inclusion of this short interview to expand the bases of interpretation for the experiment as a whole. The interviews were tape recorded and transcribed for further analysis.

\subsection{Data Analysis}

For scoring the reading span test, it was followed what is proposed by Torres (2003). Participants were given credit if they recalled the final word in the correct order of presentation and made the right decision on grammaticality. Half mark was given when participants were right in two out of the three sets. A participant was assigned as being at the span level at which he/she was correct on two out of the three sets (DANEMAN; CARPENTER, 1980; TORRES, 2003). Participants were classified as higher or lower spans according to their scores on the reading span test, on a scale of 0.5 to 5.0. In the present study, participants who scored from 2,0 and 2,5 were classified as lower spans and those who scored 3,0 and 3,5 were classified as higher spans as can be seen in Table 1. As explained by Tomitch (2003), there is not much agreement in the literature to what constitutes high/low spans readers. Therefore, this study considers weaker readers those between 2,0 to 2,5 score (mean 2,37) as lower spans and better readers those who scored 3,0 and upper (mean $3,21)$ as higher spans. 
Table 1 - Scores on the Reading Span Test

\begin{tabular}{cc}
\hline Better readers & Weaker readers \\
\hline 3,0 & 2,0 \\
3,5 & 2,5 \\
3,0 & 2,5 \\
3,0 & 2,5 \\
3,0 & Mean
\end{tabular}

\begin{tabular}{rr} 
& 3,0 \\
& 3,5 \\
& 3,5 \\
\hline Mean & 3,21
\end{tabular}

As regards the questions formulated, data consisted of 110 questions (55 for each text). All participants' questions were analyzed by these researchers, individually, to categorize each question (textually implicit, scripturally implicit, textually explicit, linguistic, miscomprehension - each type of question will be explained and exemplified in the analysis section below). After that, the analyses were compared, and we reached an agreement of 93,6\% (104 out of the 110 questions). The other 7 questions $(6,3 \%)$ were discussed until a consensus was reached.

The choice of the statistical correlation tests was based on the observation of the values of skewness and kurtosis, on the test results of ShapiroWilk and on the visual inspection of box plots and Q-Q plots to determine the results of normality tests. Therefore, based on the data of the normality tests for all the variables, Pearson's (parametric) and Spearman's rho (non-parametric) correlation tests were chosen.

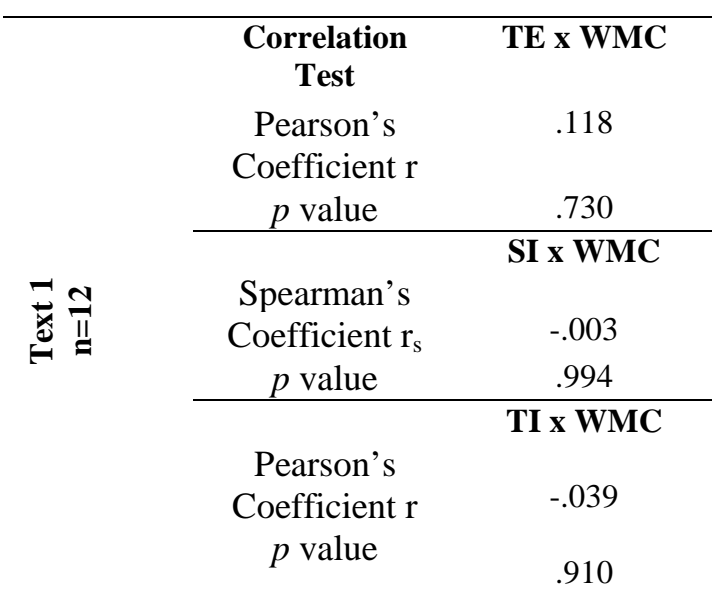

Table 2 - Statistical tests for Text 1 - Like hitting a wall

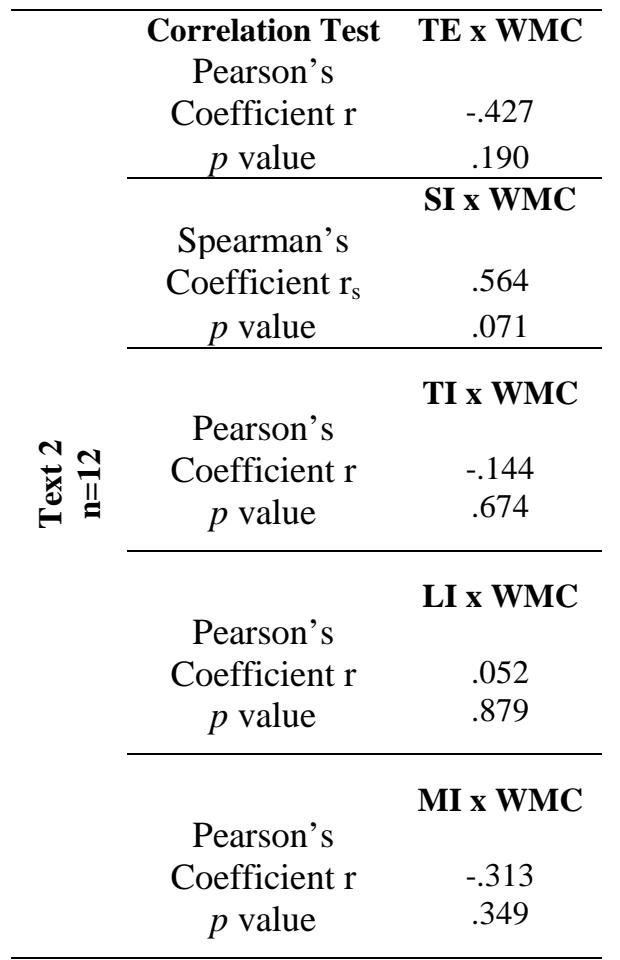

Table 3 - Table 2 - Statistical tests for Text 2 - Melting away

\section{Results and discussion}

Following DuBravac and Dale's (2002) categorization, an extension of Pearson and Johnson's (1978, as cited in DuBRAVAC; DALLE, 2002, and OLIVEIRA, 2000), the 110 questions originated in this study were categorized according to the type of answer required - found in the text itself, 
i.e., textually explicit and/or linguistic (italics will be used to highlight the category of the questions under discussion) or derived from the reader's prior knowledge, i.e., scripturally implicit and/or textually implicit. DuBravac and Dalle added another category, namely miscomprehension.

As expected, since the participants of this study are proficient readers, only two questions were categorized under the linguistic and miscomprehension categories. Linguistic question relates to syntax or semantic aspects of the text, as for instance:

"What do you mean by pristine powder?" (participant 01 referring to Text 2: Melting Away)

It is quite probable that participant 01 meant "understand" in this question since she seems to be interested in 'checking' the meaning of the expression which has to be drawn from the context: "Photos of sunburned skiers on pristine powder don't cut it anymore". Miscomprehension question corresponds to readers' inability to comprehend or grasp a coherent meaning of the text, as we can detect in:

"Why don't they create more adventurous attractions in the ski resorts?" (participant 06, Text 2)

The participant asked this question just after paragraph three of Melting away which is followed by the information that the most successful alpine resorts have invested in specialized activities such as horseback riding, paragliding, rafting and others. It is evident that the question asked is in contradiction to what is said in the text, revealing the participant's miscomprehension of this excerpt.

Scripturally implicit question requires the reader's greatest amount of background knowledge, since the answer is not in the text and the reader has to make inferences in order to find the answer:

"What other technological improvements do you think have had unintended consequences and what were these consequences?" (participant 02, Text 1)

"Can you explain how 'recreation fatigue' might be the main reason for the Alps not being a common destination for Europeans anymore"? (participant 10, Text 2)
As one can observe when reading texts 1 and 2, although these two concepts (technological improvements and recreation fatigue) are discussed in paragraphs 1 and 3 respectively, there is no direct answer provided in the texts. Therefore, to answer the question by participant 02 , the reader has to reconstruct information provided in the text to judge what other technological improvements have had unintended consequences. To answer the question raised by participant 10 , the reader must be able to evaluate information presented in the text so as to draw conclusions and pose her own assumptions.

Textually implicit questions demand less background knowledge, but a certain amount of inferencing is still needed, as for instance, when the reader has to connect two parts of a text when no explicit cue is given:

"Why do children get killed in car accidents?" (participant 3, Text 1)

"Why did the head of the regional tourist agency in Carinthia say "the good times are over? (participant 4, Text 2)

To answer these two questions the reader has to state relationships between information given throughout the paragraphs.

On the other hand, textually explicit question is the one that asks for information right in front of the reader's eyes (OLIVEIRA, 2000) demanding very little, if any, background knowledge:

"How many people have died and how many have been saved by airbags since its use became compulsory?" (participant 05, Text 1)

"What leisure options are being provided by the successful hotels in the area?" (participant 08, Text 2)

Just by checking the last paragraph of Text 1 and paragraph four of Text 2 the reader is able to answer these two questions; the only cognitive operation involved is identifying a number and naming the options provided in the texts. 
Table 4 summarizes the types of questions generated for each of the texts used in this study.

\begin{tabular}{lcccc}
\hline Question type & $\begin{array}{c}\text { Text 1 } \\
\text { Like } \\
\text { hitting } \\
\text { a wall }\end{array}$ & $\begin{array}{c}\text { Text 2 } \\
\text { Melting } \\
\text { away }\end{array}$ & Total & $\%$ \\
\hline Linguistic & -- & 1 & 1 & 0,90 \\
Miscomprehension & -- & 1 & 1 & 0,90 \\
Scripturally implicit & 14 & 6 & 20 & 18,18 \\
Textually implicit & 14 & 9 & 23 & 20,90 \\
Textually explicit & 27 & 38 & 65 & 59,09 \\
\hline
\end{tabular}

Table 4 - Frequency of questions by type

Overall, the most dominant question type was the textually explicit $(59,09 \%)$ which is in agreement with DuBravac and Dalle's (2003) and Miciano's (2004) findings. This figure is also in accordance with the literature that establishes that readers tend to generate few inferences when reading exposition (GRAESSER; KREUZ, 1993; NARVAEZ; VAN DEN BROEK; RUIZ, 1999) originating therefore, more memory-based questions. Several researchers have provided various reasons for this fact: narratives elicit more interest and promote more explanations and predictions than exposition; readers have extensive practice with narratives and everyday life is constructed in a story-like fashion. Expository texts have variable structure, contrary to narratives that activate schema and script structures supporting thus, inference generation (for a detailed review, see NARVAEZ; VAN DEN BROEK; RUIZ, 1999).

Textually implicit questions that require some amount of inference come far behind in second and scripturally implicit, the most demanding type of question because requires higher-level processing, comes in third. The fact that only two questions relate to linguistic and or miscomprehension emphasizes the level of proficiency of the readers analyzed in this research.

Regarding the first research question of this study, i.e., if there is a significant correlation between textually implicit and scripturally implicit questions and working memory capacity, there was not a statistically significant correlation for either of the variables, as described as follows. Regarding Text 1, Like hitting a wall, a Pearson's Correlation Test run between the variables textually implicit questions and working memory capacity yielded a not statistically significant correlation ( $r=-.039, n=11, p>.05)$. A Spearman's Rank Order Correlation Coefficient Test revealed a not statistically significant correlation between the variables scripturally implicit questions and working memory capacity $(r=-.003, n=11, p>.05)$. In relation to Text 2, Melting away, a Spearman's Rank Order Correlation Coefficient Test revealed a not statistically significant correlation between the variables textually implicit questions and working memory capacity $(r=-.144, \mathrm{n}=11, \mathrm{p}>.05)$. A Spearman's Rank Order Correlation Coefficient Test revealed a not statistically significant correlation between the variables scripturally implicit questions and working memory capacity $(r=.564, n=11, p>$ .05). Given the fact that results were not statistically significant, quite probable because of the limited number of participants, the researchers decided to use percentages to better visualize the performance of the participants and to pursue the answers for the research questions proposed.

To answer the second research question of this study, i.e., if there is a significant difference between the types of questions elaborated in the two expository texts, we can see from Table 5 that Text 1 , considered more difficult than Text 2 for all the participants, generated significantly more scripturally and textually implicit questions, suggesting that more inferences were made while reading the first text.

\begin{tabular}{lcc}
\hline Question type & Text & Text 2 \\
& 1 & Melting \\
& Like & away (\%) \\
& hitting & \\
& a wall & \\
& $(\%)$ & \\
\hline Linguistic & -- & 1,81 \\
Miscomprehension & -- & 1,81 \\
Scripturally implicit & 25,45 & 10,90 \\
Textually implicit & 25,45 & 16,36 \\
Textually explicit & 49,09 & 69,09 \\
\hline
\end{tabular}

Table 5 - Frequency of questions by type and texts

This difference may be explained by the acknowledgement of the participants that although they did not considered Text 1 "very" difficult, it was somewhat more complex than the second, firstly because of the topic which is not something they are 
used to read about and second, because of the technical terms, acronyms and figures. In this way, it is plausible to conclude that readers activated their background knowledge more often while reading Text 1, thus generating more scripturally implicit and textually implicit questions in order to construct or update a coherent situation model of the text (KINTSCH; VAN DIJK, 1978; VAN DIJK; KINTSCH, 1983; SUH; TRABASSO, 1993; GERNSBACHER, 1997; KINTSCH; RAWSON, 2013). The second text, more connected to the participants' personal experience since they live in a touristic city, did not trigger so much inferencing because it matched their existing knowledge to the extent that information was passively mapped into existing slots in the participants' background knowledge about the given situation (LEHMAN; SCHRAW, 2002), a fact that triggered more textually explicit questions.

The third question of this research aimed at verifying if participants with higher working memory capacity formulate more textually implicit and scripturally implicit questions than those with lower working memory. As can be visualized in Table 6, the results have to be analyzed with caution. For the three participants who scored higher in the reading span test in this study $(3,5)$, two participants (02 and 10) asked a considerable amount (80\%) of textually implicit and scripturally implicit questions whereas participant 09 only asked questions that were explicitly stated in the text.
Regarding the four participants who scored 3,0 - also considered as higher spans in this study - one can observe that three of them raised only $30 \%$ of questions that imply some form of inferencing, i.e., activation of background knowledge, contrary to participant 07 who has $60 \%$ of her questions in the textually or scripturally implicit modes.

Considering the frequency of questions raised by the weaker / low span readers (2,0 and 2,5), one can observe that participants 03 and 06 overcame the just mentioned better / higher span readers with a percentage of $40 \%$ and $60 \%$ of textually implicit and scripturally implicit questions, respectively. Participant 08 , on the other hand, followed the single pattern of textually explicit information in formulating her questions.

To better verify the difference in performance between better and weaker readers, and in pursuing to answer the fourth question of this research, the frequency and type of questions formulated by the readers were separated by texts. Although the two texts used as stimuli are quite similar (see method section), the answers provided by the participants during the interview section, and the results analyzed so far, added to some empirical studies (NARVAEZ; VAN DEN BROEK; RUIZ, 1999; LEHMAN; SCHRAW, 2002), suggest that readers might have performed differently while reading the two texts. According to the figures displayed in Table 5, one can see that on the whole, readers did have a different performance when approaching the two texts, since they produced twice more inferences while reading Text 1.

Table 6 - Individual frequency of questions and working memory capacity

\begin{tabular}{|c|c|c|c|c|c|c|c|c|c|}
\hline \multirow[b]{2}{*}{$\mathrm{P}$} & \multirow[b]{2}{*}{$\begin{array}{l}\mathrm{W} \\
\mathrm{M} \\
\mathrm{C}\end{array}$} & \multicolumn{4}{|c|}{$\begin{array}{c}\text { Type and frequency of questions } \\
\text { Like hitting a wall }\end{array}$} & \multicolumn{4}{|c|}{$\begin{array}{l}\text { Type and frequency of questions } \\
\text { Melting away }\end{array}$} \\
\hline & & $\begin{array}{c}\text { Textually } \\
\text { explicit }\end{array}$ & $\begin{array}{l}\text { Scripturally } \\
\text { implicit }\end{array}$ & $\begin{array}{l}\text { Textually } \\
\text { implicit }\end{array}$ & $\begin{array}{c}\text { (\%) of } \\
\text { Scripturally } \\
\text { implicit and } \\
\text { Textually } \\
\text { implicit }\end{array}$ & $\begin{array}{c}\text { Textually } \\
\text { explicit }\end{array}$ & $\begin{array}{c}\text { Scripturally } \\
\text { implicit }\end{array}$ & $\begin{array}{l}\text { Textually } \\
\text { implicit }\end{array}$ & $\begin{array}{c}\text { (\%) of } \\
\text { Scripturally } \\
\text { implicit and } \\
\text { Textually } \\
\text { implicit }\end{array}$ \\
\hline 01 & 3,0 & 3 & - & 2 & 40 & 3 & - & 1 & 20 \\
\hline 02 & 3,5 & - & 5 & - & 100 & 2 & 3 & - & 60 \\
\hline 03 & 2,0 & 2 & 1 & 2 & 60 & 4 & - & 1 & 20 \\
\hline 04 & 3,0 & 3 & 1 & 1 & 40 & 4 & - & 1 & 20 \\
\hline 05 & 3,0 & 3 & 1 & 1 & 40 & 4 & - & 1 & 20 \\
\hline 06 & 2,5 & - & 3 & 2 & 100 & 3 & - & 1 & 20 \\
\hline 07 & 3,0 & 1 & 3 & 1 & 80 & 3 & 2 & - & 0 \\
\hline 08 & 2,5 & 5 & - & - & 0 & 5 & - & - & 0 \\
\hline 09 & 3,5 & 5 & - & - & 0 & 5 & - & - & 0 \\
\hline 10 & 3,5 & 1 & - & 4 & 80 & 1 & 1 & 3 & 80 \\
\hline 11 & 2,5 & 4 & - & $\frac{1}{\text { Mean }}$ & $\begin{array}{c}20 \\
50.90\end{array}$ & 4 & - & 1 & $\begin{array}{c}20 \\
23.63\end{array}$ \\
\hline
\end{tabular}


Again, one has to remember that participants acknowledged their lack of background knowledge regarding the issue related to air bags regulations.

As demonstrated by several empirical studies (AFFLERBACH, 1990; KAMAS; REDER, 1995; KINTSCH; FANZKE, 1995; DAROS, 2016) readers with less background knowledge tend to have problems in understanding a text. Nevertheless, since the readers of this study are proficient and may have some background knowledge on the topic, they were able to activate their "air bag schema" and consequently, generated appropriate inferences for constructing a coherent meaning of the text. This processing was not necessary for reading Text 2 which according to the readers was easier than the first, even though slightly more lexically dense (according to systemic functional linguistics, the more lexically dense a text is, the more difficulties readers have to comprehend it (EGGINS, 1994)).

Table 7 - Working memory capacity and type and frequency of questions by text

\begin{tabular}{c|cccc|c}
\hline & \multicolumn{4}{|c|}{ Type and frequency of questions } & Working \\
\cline { 2 - 5 } Participant & $\begin{array}{c}\text { Textually } \\
\text { explicit }\end{array}$ & $\begin{array}{c}\text { Scripturally } \\
\text { implicit }\end{array}$ & $\begin{array}{c}\text { Textually } \\
\text { implicit }\end{array}$ & $\begin{array}{c}\text { (\%) of } \\
\text { Scripturally } \\
\text { implicit and } \\
\text { Textually implicit }\end{array}$ & \\
capacity \\
\hline 01 & 6 & - & 3 & 30 & 3,0 \\
02 & 2 & 8 & - & 80 & 3,5 \\
03 & 6 & 3 & 1 & 40 & 2,0 \\
04 & 7 & 2 & 1 & 30 & 3,0 \\
05 & 7 & 1 & 2 & 30 & 3,0 \\
06 & 3 & 3 & 3 & 60 & 2,5 \\
07 & 4 & 5 & 1 & 60 & 3,0 \\
08 & 10 & - & - & 0 & 2,5 \\
09 & 10 & - & - & 0 & 3,5 \\
10 & 2 & 1 & 7 & 80 & 3,5 \\
11 & 8 & - & 2 & 20 & 2,5 \\
\hline
\end{tabular}

Considering now the percentages of higher and lower spans while tackling the two texts, one can see that excepting participant 09 who only formulated textually explicit questions and participant 10 who raised the same percentage of scripturally implicit and textually implicit questions in both texts, as mentioned previously, all the other higher spans produced more of these two types of questions when reading Text 1. The same pattern applies for participants 03 and 06, who, although considered lower spans according to their score in the reading span test, produced similar, and, in some cases, better results than those considered higher spans (compare for instance, the frequency of scripturally implicit and textually implicit questions of participants 01, 04, 05 and 09). Participant 08, as already highlighted previously, did not produce any scripturally or textually implicit question and participant 11 produced the same amount of these types of questions in both texts. In sum, on the average, higher spans tended to formulate scripturally and textually implicit questions more often than lower spans in both texts, as demonstrated in Figure 1, suggesting that better readers are more prone to generate inferences, especially when the task poses a "challenge" for them, which seemed to be the case in Text 1, where readers had to count on their previous knowledge to better understand the text.

Figure 1 - Percentage of scripturally and textually implicit questions by higher and lower spans across the two texts
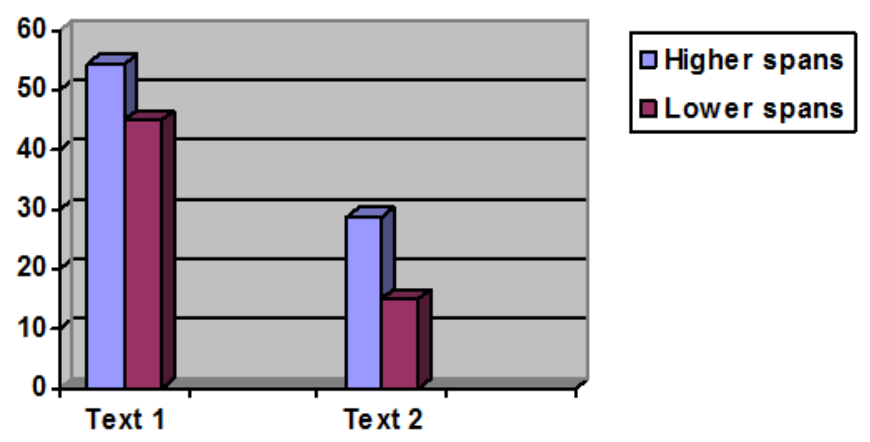

The overall results presented above corroborate previous findings in terms of the differences presented by better and weaker readers' comprehension and generation of inferences (WHITNEY; RITCHIE; CLARK, 1991; DUBRAVAC; DALLE, 2002; LINDERHOLM; VAN DEN BROEK, 2002; TOMITCH, 2003; TORRES, 2003, BARETTA; TOMITCH; McNAIR; LIM; WALDIE, 2009; BARETTA; TOMITCH; LIM; WALDIE, 2012 and others). Nevertheless, two unexpected findings were encountered in this study and will be discussed in the remaining part of this section.

The first finding that called these researchers' attention was the high frequency of textually explicit questions formulated by the readers of this study. 
Although it was expected that this type of question was more pronounced than the two other implicit types, as already found by other empirical studies, the percentage of $59,09 \%$ was surprising for two main reasons. First, because the participants of this study are all proficient readers who are used to read academic texts and therefore were expected to generate more inferences than the $\mathrm{L} 2$ beginners or intermediate readers from DuBravac and Dale's and Miciano's research and, secondly, because all of them are or have been language teachers. Considering the interviews with the participants, it was observed that this last reason may, in fact, account for an explanation for the high number of textually explicit questions. As stated by the great majority of the participants, they focused on the main ideas of the texts for considering that the instructions asked for verifying someone else's comprehension of the text. It seems that the readers in this study tended to consider their students as the audience for their questions - as emphasized by some of them. According to some studies, teachers tend to concentrate on questions that are in front of the students' eyes, especially when reading in L2 (GEROT, 2000; DAY; PARK, 2005). On the other hand, as discussed above, another possibility for the high frequency of explicit questions is the type of text - exposition - and the information presented - facts and details about general knowledge - that may not have been a good trigger for integrating readers' relevant knowledge and textbase.

The other figures that did not met our expectations are related to the types and frequency of questions raised by participant 09 - higher span reader - and participants 03 and 06 - lower spans. Considering the percentages obtained for the formulation of scripturally and textually implicit questions by these participants in the two texts, that is, $0 \%, 40 \%$ and $100 \%$, respectively (see Table 7 ), one may question the role working memory capacity plays on language comprehension. As mentioned earlier, these results must be analyzed carefully. First, and probably most relevant of all, it is important to consider the sample size of this study. 11 participants is a (too) small number, especially if we consider other studies in the area of individual differences in working memory capacity which tend to use near to a hundred subjects, as highlighted by Torres (2003). Secondly, when the participants' interviews were analyzed, it was noticed that participant 09 evaluated both texts at the intermediate level and when asked to explain how she formulated her questions, she reported trying to "make people relate to ideas in the text (...) to get the thing that was being talked about, the main ideas and make students relate them with the supporting details". As one can conclude, this reader had no problems in understanding the textbase and for this reason, did not feel the need to activate her previous knowledge, i.e., generate inferences, contrary to participant 03 who acknowledged having problems in comprehension which urged rereading of some portions of the text to ask a question, as demanded by the task. Participant 06, on the other hand, reported that her questions were formulated by what she "would like to find in the following paragraphs" and those expectations were created in her mind.

Considering the literature on working memory capacity, several researchers have established that performance differences among readers of different working memory capacity may be small when the comprehension task is easy (JUST; CARPENTER, 1992; BADDELEY, 2011). It may be the case that the comprehension task designed to test comprehension in this study was not demanding enough to constrain the comprehension of the lower-spans given their L2 level of proficiency and the high coherence of the two texts. Furthermore, as stated by Lorch Jr., Klusewitz and Lorch (1998) and by Linderholm and van den Broek (2002), there is this hypothesis that readers use strategies to compensate their low working memory capacity. Among these strategies, is the identification of information to be retained in memory for further integration with other portions. Therefore, it sounds reasonable to conclude that the lower span readers of this study have developed idiosyncratic strategies to cope with their limitations in working memory capacity in order to increase their "amount of activation they have available for meeting the computational and storage demands of language processing" (JUST; CARPENTER, 1992, p. 124). 


\section{Final remarks}

The objective of this study was to analyze how working memory capacity and the ability to generate inferences, i.e, elaborate questions that are implicitly stated in expository prose are correlated. In sum, even though there was not a statistically significant correlation between textually implicit and scripturally implicit questions and working memory capacity, we could observe that higher spans did tend to ask more questions derived from the reader's prior knowledge (average rate of $44,28 \%$ ) than lower spans (average rate of $30 \%$ ), suggesting that they were more able to construct a more coherent mental representation of the text than the lower spans, corroborating previous studies.

This research does have some limitations. First, the number of participants is limited and should be enlarged so as the results found can be replicated to verify if there is statistical significance in the correlation between the types of questions formulated by the readers and working memory capacity. Second, more difficult, distorted or low coherence texts should also be considered as stimuli to increase the demands of working memory and the generation of inferences in order to construct meaning from texts. Third, another comprehension measure should be considered besides the formulation of questions to triangulate the scores with the reading span test as did by Tomitch (2003), so as to verify the validity of question formulation as a measure of reading comprehension. Fourth, the procedures adopted by Miciano's (2004) in data collection - there was no limit for the frequency nor a specific place for formulating questions - should be considered in future research, specially if one is considering the role of inferences in comprehension. Finally, following DuBravac and Dalle's (2002) suggestion, a reading comprehension test elaborated from the questions formulated by the participants could be applied some time after the initial experiment to compare the results between this interval, that is, what type of questions improved retention and how and to what extent this is related to working memory capacity.

Despite its limitations the present study is a step in the attempt to scrutinize he relationship between working memory capacity and reading comprehension through the scope of question formation. An issue which also deserves further scrutiny is the use of question formation as a reading comprehension predictor.

\section{Referências}

AFFLERBACH, P. P. The influence of prior knowledge on expert's readers' main Idea construction strategies. Reading Research Quarterly, XXV, 1, p. 31-46, 1990.

BADDELEY, A. D. Human Memory: theory and Practice. Boston: Allyn \& Bacon, 1998.

BADDELEY, A. D.; HITCH, G. Working Memory: psychology of learning and motivation, 8, p. 47-90, 1974.

BADDELEY, A. Memória de Trabalho. In: BADDELEY, A.; ANDERSON, M. C.; EYSENCK, M.W. Memória. Porto Alegre: ARTMED, 2011, p. 54-82.

BARETTA, L. The performance of proficient EFL readers when reading to recall and to summarize expository texts. 1998. 191f. Dissertação (Mestrado em Letras Inglês). Universidade Federal de Santa Catarina, Florianópolis, outubro, 1998.

BARETTA, L. A performance de leitores proficientes em inglês versus tarefa de leitura. ROTEIRO: Revista científica da UNOESC - Campus de Joaçaba, v. 28, n.1, p. 41-56, 2003.

BARETTA, L.; TOMITCH, L.M.B.; LIM, V. K.; WALDIE, K. E. Investigating reading comprehension through EEG. Ilha do Desterro, 63, p. 69-99, 2012.

BARETTA, L.; TOMITCH, L.M.B.; McNAIR, N.; LIM, V. k.; WALDIE, K. E. Inference making while reading narrative and expository texts: An ERP study. Psychology \& Neuroscience, v. 2, n.2, p. 39, dez, 2009.

CARPENTER, P., MYIAKE, A.; JUST, M.A. Working memory constrains in comprehension: evidence form individual differences, aphasia and aging. In: GERNSBACHER, M.A. (ed.). Handbook of psycholinguistics. New York: Academic Press, 1994. 
CARR, E.; OGLE, D. K-W-L Plus: a strategy for comprehension summarization. Journal of Reading, V.30, nr.7 (April), p. 626-631, 1987.

CARRELL, P.L. Awareness of text structure: effects on recall. Language Learning, v. 42, n. 1, p. 1-20, 1992.

DANEMAN, M. Working Memory as a Predictor of verbal Fluency. Journal of Psycholinguistic Research, 6, p. 445-463, 1991.

DANEMAN, M.; CARPENTER, P. Individual differences in working memory and reading. Journal of verbal Learning and verbal behavior, 19, p. 450-466, 1980.

DANEMAN, M.; CARPENTER, P. Individual differences in integrating information between and within sentences. Journal of Experimental Psychology: learning, memory and cognition, 9, p. 561-584, 1983.

DANEMAN, M.; GREEN, I. Individual differences in comprehending and producing words in context. Journal of Memory and Language, 25, p. 1-18, 1986.

DAROS, E.G. A leitura de textos em Língua Materna e Estrangeira com Estudantes da EJA: Estudo de Estratégias. 2016. 182f. Dissertação (Mestrado em Letras). Universidade Estadual do Centro-Oeste, Guarapuava, 2016.

DAVIES, F. Introducing Reading. London: Penguin books, 1995.

DAY, R.R.; PARK, J. Developing reading comprehension questions. Reading in a foreign language, v. 17, n.1, April 2005.

DUBRAVAC, S.; DALLE, M. Reader question formation as a tool for measuring comprehension: narrative and expository textual inferences in a second language. Journal of Research in reading, v. 25, n. 2, p. 217-231, 2002.

EGGINS, S. An introduction on systemic functional linguistics. Pinter Publishing, 1994.

ELLIS, R. The Study of Second Language Acquisition. Oxford University Press, 1994.

ENGEL, R. Melting away. Newsweek, 29, p.29, March 1996.

FORTKAMP, M. B. M. Working Memory Capacity and L2 Speech Production: an exploratory study. Tese (Doutorado em Letras Inglês). Universidade Federal de Santa Catarina. (UFSC). Florianópolis, 2000.

GERNSBACHER, A.M. Two decades of structure building. Discourse processes, 23, p. 265-304, 1997.
GEROT, L. Exploring reading process. In: UNSWORTH, L. (ed.). Researching language in schools and communities: Functional linguistic perspectives. London. CASSELL, 2000, p. 204221.

GOLDMAN, S.R. Learning from text: reflections on the past and suggestions for the future. Discourse Processes, 23, p. 357-398, 1997.

GRAESSER, A.C.; KREUZ, R.J. A theory of inference generation during text comprehension. Discourse Processes, v.16, 3, 1993.

GUARÁ TAVARES, M.G. Pre-task planning, working memory capacity, and L2 speech performance. 2008. 236f. Tese (Doutorado em Letras Inglês). Universidade Federal de Santa Catarina, Florianópolis, maio 2008.

HALLDORSON, M.; SINGER, M. Inference processes: integrating relevant knowledge and text information. Discourse processes, v. 34, n. 2, p. 145-161, 2002.

HARE, V. C. Summarizing text. In: IRWIN, J. W.; DOYLE, I. (Eds.), Reading / Writing connections: learning from research. Newark, DEL: International reading association, 1992, p.96-118.

HOEY, M. On the surface of discourse. London: George Allen \& Unwin, 1983.

JUST M.A.; CARPENTER, P. A capacity theory of comprehension: individual differences in working memory. Psychological review, 99, p.122-149, 1992.

KAMAS, E.N.; REDER, L.M. The role of familiarity in cognitive processing. In: LORCH, R.F.; O'BRIEN, R.F. (Eds.). Sources of coherence in reading. New Jersey, USA: LEA, 1995. p. 177-200.

KINTSCH, W.; FRANZKE, M. The role of background knowledge in the recall of a news story. In: LORCH, R.F. O'BRIEN, R.F. (Eds.). Sources of coherence in reading. New Jersey, USA: LEA, 1995, p. 321-333.

KINTSCH, W.; VAN DIJK, T. A. Toward a model of text comprehension and production. Psychological Review, v. 85, n. 5, p/ 363-394, 1978.

KINTSCH, W.; RAWSON, K.A. Compreensão. IN: SNOWLING, M.J.; HULME, C. (orgs.). A ciência da leitura. Porto Alegre: Penso Editora, 2013, p. 227-244.

KLAIDMAN, D. Like hitting a wall. Newsweek, p. 39, November 1996.

LEHMAN, S.; SCHRAW, G. Effects of coherence and relevance on shallow and deep text processing. Journal of Educational Psychology, v. 94, n.4, p. 438-750, 2002. 
LINDERHOLM, T.; VAN DEN BROEK, P. The Effects of reading purpose and working memory capacity on the processing of expository texts. Journal of Educational Psychology, v. 94, n. 4, p. 778-784, 2002.

MATIELO, R. Intralingual subtitles, interlingual subtitles, and $L 2$ vocabulary learning: an exploratory study with Brazilian EFL students. 2016. 272f. Tese (Doutorado em Inglês: Estudos Linguísticos e Literários). Universidade Federal de Santa Catarina, Florianópolis, março, 2016.

MICIANO, R.Z. The content and form of readergenerated questions: implications for teaching questioning strategies. Asia Pacific Education Review, v. 5, n. 2, p. 149-156, 2004.

NARVAEZ, D.; VAN DEN BROEK, P.; RUIZ, A.B. The influence of reading purpose on inference generation and comprehension in reading. Journal of Educational Psychology, v. 91, n. 3, p. 488-496, 1999.

O'BRIEN, E.J. Automatic components of discourse comprehension. In: LORCH F.R.J.; O'BRIEN, E. J. (Eds.) Sources of coherence in reading. Lawrence Erlbaum Associates. Hillsdale, New Jersey, 1995. p. 159-76.

OLIVEIRA, S. Question-asking in Brazilian Portuguese reading comprehension textbooks. Ilha do Desterro, n. 38, p. 39-56, 2000.

PARIS, S.G.; LIPSON, M. Y.; WIXSON, K.K. Becoming a strategic reader. Contemporary Educational Psychology, 8, p. 293-316, 1983.

RILEY, G. L.; LEE, J. F. A comparison of recall and summary protocols as measures of second language reading comprehension. Language testing, 1, p. 173-187, 1996.

SINGER, M.; ANDRUSIAK, P.; REISDORF, P.; BLACK, N. Individual differences in bridging inference processes. Memory \& Cognition, v. 20, n.5, p. 539-548, 1992.

SUH, S.; TRABASSO, T. Inferences during reading: converging evidence from discourse analysis, talkaloud protocols and recognition priming. Journal of memory and language, 32, p. 279-300, 1993.

TOMITCH, L. M. B. Individual differences in text organization perception and working memory capacity. Revista da ANPOLL, 2, p. 71-93, 1996.

TOMITCH, L. M. B. Individual differences in working memory capacity and the recall of predicted items in the text. Lenguas Modernas, p. 26-27, p. 3-51, 1999-2000.

TOMITCH, L. M. B. Reading: text organization perception and working memory capacity. Florianópolis: UFSC, Departamento de língua e literaturas estrangeiras, 2003.

TORRES, A. C. G. Working memory capacity and readers' performance on main idea construction in L1 and L2. Tese (Doutorado em Letras Inglês). Universidade Federal de Santa Catarina, Florianópolis, 2003.

TRABASSO, T.; MAGLIANO, J.P. Conscious understanding during comprehension. Discourse Processes, 21, p. 255-287, 1996.

MAGLIANO, J.P.; TRABASSO, T.; GRAESSER, A.C. Strategic processing during comprehension. Journal of Educational Psychology, v.91, n.4, p. 615-629, 1999.

VAN DEN BROEK, P.; RISDEN, K.; FLETCHER, C.R.; THURLOW, R. A "landscape" view of reading: fluctuating patterns of activation and the construction of a stable memory representation. In: BRITTON, B.C.; GRAESSER, A.C. (eds.) Models of Understanding text. Lawrence Erlbaum Associates. Hillsdale, New Jersey, 1995. p. 16587.

VAN DEN BROEK, P.; RISDEN, K.; HUSEBYEHARTMANN. The role of readers' standards for coherence in the generation of inferences during reading. In: LORCH, R.F.J; O' O'BRIEN, E. J. (Eds.) Sources of coherence in reading. Lawrence Erlbaum Associates. Hillsdale, New Jersey, 1995. p. 353-373.

VAN DIJK, T.A.; KINTSCH, W. Strategies of discourse comprehension. New York: Academic Press, 1983.

ZWAAN, R.A.; BROWN, C.M. The influence of language proficiency and comprehension skill on situation-model construction. Discourse Processes, 21, p. 289-327, 1996.

WHITNEY, P.; RITCHIE, B. G.; CLARK, M. B. Working memory capacity and the use of elaborative inferences in text comprehension. Discourse Processes, v.14, p. 133-145, 1991.

WINOGRAD, P. N. Strategic difficulties in summarizing texts. Reading Research Quarterly, xix, 4, p. 404-425, 1984.

WOLF, D. A comparison of assessment tasks used to measure FL reading comprehension. Modern Language Journal, 77, p.473-89, 1993. 


\section{COMO CITAR ESSE ARTIGO}

BARETTA, Luciane; TAVARES, Maria da Glória Guará. Question Formation and Working Memory Capacity on L2 Reading Comprehension. Signo, Santa Cruz do Sul, v. 43, n. 77, jul. 2018. ISSN 1982-2014. Disponível em: $<$ https://online.unisc.br/seer/index.php/signo/article/view/12247>. Acesso em: doi: http://dx.doi.org/10.17058/signo.v43i77.12247. 